Early Theatre 7.2 (2004)

\title{
Issues in Review
}

Viviana Comensoli, Theodora A. Jankowski, Bryan Reynolds

Subjectivity, Theory, and Early Modern Drama

\section{Introduction}

Over the past two decades, various schools of poststructuralist theory and criticism, including various branches of feminism, new historicism, cultural materialism, and psychoanalysis, have brought complex questions to bear on the conceptualization and representation of subjectivity in the early modern theatre, guiding out thinking about the term as a historically and discursively contingent, performative construct. In 1985 Catherine Belsey, in The Subject of Tragedy, identified two competing views of the human subject as operative in early modern European culture and theatrical practices: one, the medieval idea of the discontinuous, fragmented self; the other, what Belsey characterized as an incipient humanist notion of the stable, self-reflexive subject, a conceptualization that, she argued, would not be fully realized until the Enlightenment. ${ }^{1}$ More recently, literary critics and historians of the early modern period have demonstrated that the notion of the unified, self-reflexive subject was already in wide circulation during the late sixteenth century. As Sara Deats observes, antithetical views of subjectivity coexisted at this time amid competing claims about the ways in which the human subject attains knowledge, giving rise to 'an order of subjectivity that is recognizably modern'. ${ }^{2}$ Based in large part on the writings of Michel Foucault, Judith Butler, and other late-twentieth century theorists, early modern subjectivities have come to be considered as speculative and performative cultural constructs. ${ }^{3}$ Within this broad historical and semantic framework, subject performance in the early 
modern theatre has been, and continues to be, widely theorized as perpetually created and redefined in complex relation to sociopolitical and discursive pressures.

Yet the poststructuralist paradigm of the universally discontinuous subject has proved problematic in considerations of 'subjects' who have been marginalized or excluded from official culture, whether premodern or postmodern. Judith Butler herself, in Bodies that Matter, cautioned against the uncritical articulation of a theory that promotes non-essentialist subjectivities and identifications without an attendant exploration of the ideologies of exclusion that initially gave rise to those structures. ${ }^{4}$ In the late 1980 s in renaissance studies, scholars of early modern drama began to re-examine the new theoretical assumptions and methodologies that were informing our understanding of early modern subject formation and representation, with some critics concluding that one result had been the reinforcement of the universality of the white male heterosexual subject. In his influential essay, 'Political Criticism of Shakespeare', Walter Cohen, for example, critiqued the new historicism's understanding of gender in the context of the body and structures of power 'more than in relation to women'. The elision, he argued, denied women an identification as subjects: women 'can be victims or objects, but it is not . . their experience that matters'. ${ }^{5}$ In an equally provocative analysis of 'the new theoretical discourses', Carol Thomas Neely asserted that, despite what projects like new historicism, neo-Marxism, and cultural materialism 'seem to have in common with feminist criticism, ... their effect ... has been to oppress women, repress sexuality, and subordinate gender,' ultimately 're-producing patriarchy'. ${ }^{6}$ As a result of these and related interrogations, scholars interested in early modern subjectivities, including the corollaries of race, gender, and sexuality, increasingly recognized that theoretical and historical investigations needed to take into fuller account the methodologies, discourses, and ideologies that distinguish early modern cultures, and their connection to what Mary Beth Rose has called 'the otherness of the past'. ${ }^{7}$

Critical explorations of subject representation and performance on the English renaissance stage are continuing to provide valuable correctives to postmodern paradigms. ${ }^{8}$ Katharine Eisaman Maus, in Inwardness and Theater in the English Renaissance, has challenged us to rethink the theoretical commonplace that has defined the concept of 'self manifested in renaissance discourses as epistemologically 'void'; in the late sixteenth and seventeenth centuries, she argues, subjectivity is not an anachronistic category but a category (epistemological, psychological, and political) of presence rooted in the distinction between inwardness/interiority and outward or 'falsifiable' 
identity. ' In 'Professing the Renaissance: The Poetics and Politics of Culture', Louis Montrose has argued that in the early modern period the process of subjectification not only subjects individuals to cultural imperatives, but also confers agency and subjectivity, making individuals 'loci of consciousness and initiators of action'. ${ }^{10}$ And in her important studies of subjectivity, desire, and sexuality as represented in the theatre of Shakespeare and his contemporaries, Valerie Traub has urged that critical assessments of the plays address more fully the 'material and subjective experience' that led early modern individuals (actual and imaginary) to resist dominant ideological imperatives; one way of doing so, she suggests, is by approaching gender, desire, and sexuality as 'experienced not only in the contact between bodies, and between bodies and institutions, but through the experience of subjective need, want, anxiety and fulfilment'. ${ }^{11}$ Since the 1990 s revisionist scholarship on early modern subjectivities has also witnessed a growing interest in postcolonial theoretical perspectives. In her groundbreaking essay 'The Color of Patriarchy', for example, in the 1994 anthology Women, "Race," and Writing in the Early Modern Period, Ania Loomba notes that a meeting point of 'Renaissance and postcolonial studies' has been their 'common interest in marginalized peoples of different sorts, and in their disparate attempts to theorize and recover subaltern resistance (or agency)' in the context of their 'relation to power'; at the same time, however, she cautions that 'the agency of the marginalized subject is obscured when that subject is theorized as discontinuous, or as merely "the site" for the intersection of various discourses'. ${ }^{12}$

The three short essays that follow are offered in the spirit of the ongoing debate about subjectivity as a signifier of identification in the drama of early modern England. Each essay provides a different perspective on the concept, urging at the same time the need for a continuous revaluation of the theoretical questions and modes of analyses that are informing the discourse. With reference to Shakespeare's Othello, I note that while political/postcolonial readings of the play's representation of the racialized subject have taught us important ways of re-reading renaissance texts, a psychoanalytic inquiry elucidates further the early modern theatre's complicity in the colonialist articulation of Otherness. Theodora Jankowski, whose scholarship on queer theory and its applications to renaissance literary and dramatic texts has added important dimensions to our understanding of early modern cultural production, here explores Dekker's Honest Whore plays to illustrate how the alliance of queer theory with feminist and Marxist/cultural-materialist theory and criticism provides new insights into the representation of early modern subjectivities, in particular radical subject positions occupied by women. In 
his post-Derridean meditation on subject performance in Shakespeare's Macbeth, Bryan Reynolds expands upon his theory of 'transversal poetics' (which he has been developing over the past ten years) with an 'investigative-expansive' mode of analysis that he calls 'fugitive explorations', a politically and aesthetically empowering mode of critical analysis designed to challenge the disempowerment of subjects that, he argues, many forms of poststructuralist discourse have promoted. Although the three essays differ substantially in their theoretical and critical apparatus, they share two related claims: 1) the need for contemporary literary theory and criticism to attend more expansively to ideologies (both premodern and postmodern) of power, and to how those ideologies frame our discourse; and 2) the absolute need, at the beginning of the twenty-first century, for a theoretical methodology that is politically engaged and progressive.

Viviana Comensoli

\section{Identifying Othello: Race and the Colonial (non)Subject}

I offer the following brief inquiry into Shakespeare's Othello as a preamble to a longer study of the insights that contemporary psychoanalytic theory can bring to political/postcolonial questions surrounding early modern conceptualizations of subjectivity and difference. My reading of Othello's status as '(non)subject' builds on the widely accepted view of the play as upholding the Subject/Other dichotomy that underwrites western epistemologies of difference. ${ }^{13}$ Bringing to this view a contemporary psychoanalytic lens clarifies the play's implication in colonialist ideology. While the play coheres, on one hand, with the traditional Subject/Other split, a psychoanalytic reading reveals how the play ultimately excludes Othello from the Self/Other dynamic that in colonial cultures makes subjectivity possible. The question that underwrites my analysis is how, in the context of the early colonialist culture in which the English renaissance theatre operated, can characters identified as Other be represented as, in Maus's terms, having a Self, or, in Montrose's terms, as having a 'consciousness' and the capability for action?

According to a now widely accepted new-theoretical reading of the play, before Othello's capitulation to Iago's provocations, Othello, the familiar Moor of Venice, tragically deludes himself into believing that, despite his African ancestry, he is not an alien in the Venetian social hierarchy. Instead, Othello's Otherness is masked by his supreme confidence and ability as a 
military commander. Although the critic Eldred Jones subscribes to the view of the play as fashioning a tragically heroic Othello, he makes the important observation that in Othello's first speech on stage (1.2.17-28) his duty to the Venetian state is 'the one solid prop of his confidence', indeed 'the source of his security' in Venice; Othello's royal ancestry is not widely known, and after asserting that he descends 'From men of royal siege' (11. 21-2) he never refers to his ancestry again. ${ }^{14}$ That Othello's identity as a black man in the Venetian court is a marker of negativity is confirmed in the Duke's aside to Brabantio following Othello's defence of his and Desdemona's elopement: 'If virtue no delighted beauty lack, / Your son-in-law is far more fair than black' (1.3.290-1). ${ }^{15}$ Kim Hall has pointed out that images of whiteness, fairness, beauty, and chastity are juxtaposed throughout the play with the 'blackness' that indicates Othello's exclusion from élite Venetian male culture. ${ }^{16}$ When in act 3 Othello verbalizes his insecurity, nagatively comparing himself with others on the status hierarchy, he articulates his insecurity in relation to his race and age: 'Haply, for I am black, and have not those soft parts of conversation / That chamberers have, or for that I am declined / Into the vale of years' (3.3.267-70). As I have argued elsewhere, Othello's insecurity upholds the renaissance notion that a lack of ease and security distinguishes civilized from uncivilized subjects; Othello's Otherness in Venice is also underscored by his lack of interest in the arts - especially music - which sets him apart not only from Venetians but also from his heroic counterparts in other plays by Shakespeare. ${ }^{17}$ In Castiglione's Book of the Courtier, insecurity is indicative of 'baseness', whereas grace and 'sprezzatura' are the mark of the true courtier, whose 'noblenesse of birth is (as it were) a clere lampe that sheweth forth and bringeth ... into light, ... and enflameth and provoketh unto vertue, with the hope of praise'. ${ }^{18}$ In colonialist Venice, 'the color of virtue', as James Calderwood asserts, 'is not black but white'. ${ }^{19}$

Pressing the political and ideological contexts of these readings of the play further, we see that the colonialist subtext not only defines the ideal subject as élite, white, and male, but also reveals the ways in which, in early colonialist cultures like early modern Venice and Shakespeare's England, Otherness itself functions as a category of white male subjectivity. Contemporary non-European revisionist productions, re-writings, and readings of Othello provide important insights into the play's colonialist structures. In her valuable study of responses to revisionist novels and plays, Jyotsna Singh writes that African and Turkish audiences, among others, perceive Shakespeare's Othello as a figure in a recognizable 'Orientalist landscape, both erotic and violent, a composite [European] fantasy'; they are compelled to make 'both an identi- 
fication with and disavowal of the Moor', realizing that his 'claims to any identity - either as a "savage" or as a Christian and a tragic hero - are tenuous and derivative'. ${ }^{20}$ And Thomas Cartelli, in his discussion of Tayeb Salih's novel Season of Migration (originally published in Arabic in 1966), shows how Salih “"writes back" to Othello' by demystifying and rewriting the mythologies surrounding Shakespeare's character, identifying Othello as a 'construction and sentimental fantasy of the west: a noble mind undermined by a predictably primitive heart that remains cloyingly faithful to the colonizing interests that destroy him'. ${ }^{21}$

A psychoanalytic reading corroborates the claim for the play's promotion of colonialist ideology. At the same time as Othello's (self)identification accords with the conventional Subject/Other binary, his (self)representation upholds the colonialist construction of the Other as a non-subject. In his classic anti-colonialist treatise Black Skin, White Masks Frantz Fanon, whose work often invokes psychoanalytic discourse, emphasizes that in colonialist ideologies, 'the real Other for the white man is and will continue to be the black man.... The Other is perceived on the level of the body image, absolutely as the not-self - that is, the unidentifiable, the unassimilable. ${ }^{22}$ The signifier 'white man' in colonialist cultures thus monopolizes the category of the Other, securing access to subjectivity. In this process of racial othering, argues Fanon, 'Ontology ... does not permit us to understand the being of the black man. For not only must the black man be black; he must be black in relation to the white man.... The black man has no ontological resistance in the eyes of the white man'. ${ }^{23}$ The contemporary psychoanalytic theorist Diana Fuss, in her book Identification Papers, draws on Fanon's insights to suggest, 'If psychoanalysis is right to claim that "I is an Other," then otherness . . . constitutes the very entry into subjectivity; subjectivity names the detour through the Other that provides access to a fictive sense of self. ${ }^{24}$ Through this process, colonialism excludes the black man from the very Self/Other dynamic that makes subjectivity possible. For Fanon, the black man in colonialist power structures is always endlessly fragmented. The concept of 'moral consciousness' is a case in point: 'Moral consciousness', he writes, 'implies a kind of scission, a fracture of consciousness into a bright part and an opposing black part. In order to achieve morality, it is essential that the black, the dark [man] . . . vanish from consciousness', so that the black man 'is forever in combat with his own image'. ${ }^{25}$ For the white male subject, on the other hand, as Fuss points out, 'the considerable cultural capital amassed by the colonization of subjectivity amounts to nothing less than the abrogation of universality ...; the white man can be white without any relation to the 
black man because the sign "white" exempts itself from a dialectical logic of negativity'. ${ }^{26}$

In the early colonialist setting of Shakespeare's play, Othello's 'subjectivity', as measured by the visual signifiers 'white' and 'black', constitutes an Otherness that is internally chaotic and significant only in relation to what it is not. As a black man, Othello represents and upholds racial difference by becoming for the white man (embodied most fully by Iago) the repository of white male subjects' suppressed fantasies and desires. Through Iago's virulent racist attacks, together with the play's insistence on Othello's lack of the qualities that distinguish the true courtier, namely grace and sprezzatura, Othello is constructed as neither subject nor other, but, in Fanon's words, 'an object' cut off from his 'own presence'. ${ }^{27}$ Forced to represent (and uphold) the fantasy of the universal 'primitive' - 'thicklips' (1.1.65), 'old black ram' (1. 87); 'Barbary horse' (1. 110); 'gross ... lascivious Moor' (1. 124) - Othello is denied both ontological subject status and the Otherness that makes subjectivity possible. As a substitute-mechanism for real alterity, 'objecthood', writes Fuss, 'blocks the migration through the Other necessary for subjectivity to take place'. ${ }^{28}$

In the final scene of the play the only surviving characters on stage are élite white men. Although the audience is invited to pity Othello for the suffering and calamity that have led to his death, we are also invited to accept Othello's downfall as an inevitable function of his transgression, which is rooted in his exclusion from subjectivity altogether.

Viviana C omensoli

\section{Notes}

1 Catherine Belsey, The Subject of Tragedy: Identity and Difference in Renaissance Drama (London, 1985).

2 Sara Munson Deats, Sex, Gender, and Desire in the Plays of Christopher Marlowe (Newark and London, 1997), 219.

3 See especially Michel Foucault, The History of Sexuality, trans Robert Hurley, 3 vols. (1978; rpt. New York, 1978-1987); and Judith Butler, Bodies that Matter: On the Discursive Limits of "Sex" (New York and London, 1993), Gender Trouble: Feminism and the Subversion of Identity (New York and 
London, 1990), and 'Against Proper Objects', Differences: More Gender Trouble: Feminism Meets Queer Theory 6 (Summer/Fall 1994), 1-26.

4 Butler, Bodies that Matter, 93-119.

5 Walter Cohen, 'Political Criticism of Shakespeare', Shakespeare Reproduced: The Text in History and Ideology, Jean E. Howard and Marion F. O'Connor (eds) (New York and London, 1987), 38.

6 Carol Thomas Neely, 'Constructing the Subject: Feminist Practice and the New Renaissance Discourses', English Literary Renaissance 18.1 (Winter 1988), 7 and 9. On the uneasy alliances between new historicist and feminist discourses of gender and subjectivity, see also Karen Newman, Fashioning Femininity and English Renaissance Drama (Chicago and London, 1991), xvii-xviii.

7 Mary Beth Rose, 'Where Are the Mothers in Shakespeare? Options for Gender Representation in the English Renaissance', Shakespeare Quarterly 42 (Fall 1991), 291.

8 The works that I cite in this overview are by no means exhaustive. They represent some of the major contributions to revisionist scholarship on subjectivity and early modern drama.

9 Katharine Eisaman Maus, Inwardness and Theater in the English Renaissance (Chicago and London, 1995), 3 and 4. On the links between subjectivity, agency, and language in relation to cultural constructions of the early modern subject, see also Joel Fineman, The Subjectivity Effect in Western Literary Traditions: Essays toward the Release of Shakespeare's Will (Cambridge, MA, 1991); and Elizabeth Hanson, Discovering the Subject in Renaissance England (Cambridge, 1998).

10 Louis Montrose, 'Professing the Renaissance: The Poetics and Politics of Culture', The New Historicism, H. Aram Veeser (ed) (London, 1989), 21.

11 Valerie Traub, 'Desire and the Differences it Makes', The Matter of Difference: Materialist Feminist Criticism of Shakespeare, Valerie Wayne (ed) (Ithaca, 1991), 90-1; Desire and Anxiety: Circulations of Sexuality in Shakespearean Drama (London and New York, 1992), 8-9. Cf. Mark Breitenberg, who in Anxious Masculinity in Early Modern England (Cambridge, 1996) argues that renaissance notions of 'masculinity', for example, paradoxically promote the traditional sex-gender system and indicate pervasive ideological contradictions.

12 Ania Loomba, 'The Color of Patriarchy: Critical Difference, Cultural Difference, and Renaissance Drama', Women, "Race," and Writing in the Early Modern Period, Margo Hendricks and Patricia Parker (eds) (London and New York, 1994), 17 and 18. Other influential postcolonial studies of early modern drama are noted in my discussion of Othello below. 
13 On the play's complicity with colonialist ideology, see, for example, Martin Orkin, 'Othello and the "Plain Face" of Racism', Shakespeare Quarterly 38.2 (1987), 166-88; Dympna Callaghan, “'Othello Was a White Man”: Properties of Race on Shakespeare's Stage', Alternative Shakespeares II, Terence Hawkes (ed) (London and New York, 1996), 192-215; Margo Hendricks, “"The Moor of Venice”, or the Italian on the Renaissance English Stage', Shakespearean Tragedy and Gender, Shirley Nelson Garner and Madelon Sprengnether (eds) (Bloomington and Indianapolis, 1996), 193-209; Michael Neill, "Mulattos," "Blacks," and "Indian Moors": Othello and Early Modern Constructions of Human Difference', chapter 10 of Putting History to the Question: Power, Politics, and Society in English Renaissance Drama (New York, 2000); and Ania Loomba, 'Othello and the Racial Question', Shakespeare, Race, and Colonialism (Oxford 2002), 91-111.

14 Eldred Jones, Othello's Countrymen: The African in English Renaissance Drama (London, 1965), 90. On the view that the play accommodates the notion of Othello's heroism at the same time as it exposes Venetian ideology as fractured, see Joseph Fitzpatrick and Bryan Reynolds, 'Venetian Ideology or Transversal Power? Iago's Motives and the Means by which Othello Falls', chapter 3 of Bryan Reynolds, Performing Transversally: Reimagining Shakespeare and the Critical Future (New York, 2003).

15 William Shakespeare, Othello, E.A.J. Honigmann (ed) (1999; reprint London, 2001). All quotations from Othello will refer to this edition.

16 Kim F. Hall, Things of Darkness: Economies of Race and Gender in Early Modern England (Ithaca and London, 1995), 8-11 and 70 n. 11.

17 Viviana Comensoli, 'Music, The Book of the Courtier and Othello's Soldiership', The Italian World of English Renaissance Drama: Cultural Exchange and Intertextuality, Michele Marrapodi (ed) (Newark, NJ, 1998), 89-105.

18 The Book of The Courtier from the Italian of Count Baldassare Castiglione: Done into English by Sir Thomas Hoby, Anno 1561 (New York, 1967), 56-8 and 44.

19 James L. Calderwood, The Properties of Othello (Amherst, MA, 1989), 46.

20 Jyotsna Singh, 'Othello's Identity, Postcolonial Theory, and Contemporary African Rewritings of Othello', Women, "Race," and Writing in the Early Modern Period, 298-9.

21 Thomas Cartelli, Repositioning Shakespeare: National Formations, Postcolonial Appropriations (London and New York, 1999), 148 and 155. Cf. the Nigerian scholar S.E. Ogude's contention that 'every production of Othello is a reenactment of racial tensions, and Othello is preeminently a caricature of the black man' ('Literature and Racism: The Example of Othello', Othello: New Essays by Black Writers, Mythili Kaul (ed) (Washington, DC, 1997), 163. 
22 Frantz Fanon, Black Skin, White Masks, trans. Charles Lam Markmann (New York, 1967), 161 n. 25.

23 Fanon, 110.

24 Diana Fuss, Identification Papers (New York and London, 1995), 143.

25 Fanon, 194.

26 Fuss, 143.

27 Fanon, 112.

28 Fuss, 143.

\section{'The chick got in the way', or The Woman is/as Queer: Feminism, Queer Theory, and the Unlocking of Female Subjectivity in Early Modern Drama}

One of the most egregious comments to emerge from the recent US engagement in Iraq appeared in the press shortly after troops entered Baghdad. An Iraqi civilian woman was accidentally killed by a US soldier as he was preparing to kill someone else. When asked by reporters why he shot and killed the woman, he replied, 'The chick got in the way.' This statement has haunted me for many reasons and I want to use it to begin thinking about the intersections of feminist and queer theory.

Calling any woman a 'chick' is, of course, sexist. 'Chick' is a term we have all heard often, a term that is so much a part of the ordinary male vocabulary that it is ubiquitous and, therefore, often 'unheard'. 'Chicks', 'babes', 'broads', (fully adult) 'girls' - not to mention their more obscene counterparts - are everyday markers of the Self/Other dichotomy that necessitates feminist criticism and feminist theory. A man in a heterosexual male/patriarchal culture defines himself as Self to the exclusion of Others - women, children, aliens, and homosexuals - through the use of derogatory terms to define those who are not as he is, for whatever reasons. The woman killed by the US soldier was a 'chick' because she was a woman to this male patriarch.

The fact that this 'chick' had the temerity to 'get in the way', therefore somehow eliminating the necessity of any remorse from her killer, provokes me to look more deeply into her situation. Picture, for a moment, this woman as target. She is identifiable as female or she would not have been labelled 'chick'. But as an Iraqi, she may have been wearing a hijab or a burqa. Either of these two items of clothing would have clearly marked her as Muslim, Middle Eastern, non-western, non-Christian. To western eyes, the covering of these garments might also seem to make her invisible, to deny her humanity 
and her identity. Absent the sexualized and sexualizing clothing of many western women - especially that of the US soldier's female contemporaries? - the Iraqi woman as Other also becomes 'object' since her femaleness is so hidden. She is also an enemy civilian, a citizen of a country governed by a demonized dictator, purported terrorist, and organizer of weapons of mass destruction. As 'chick', the Iraqi woman may simply be Other to the US soldier's Self. As almost invisible covered object, Muslim, Semite, Middle Easterner, non-western, non-Christian woman, she is much more than simply Other; she is 'queer'.

Critical alliances within the world of early modern studies can probably best be defined as sporadic or fraught. Scholars become defined as one kind of critic and either have trouble breaking out of that mould, or are viewed askance when they do. Two of the most fraught areas are those in which I work: feminist theory and queer theory. Feminist theory has probably the longer history of disagreements and outright arguments, since it has produced, to my reckoning, at least three 'generations' of scholars since my initial involvement in the discipline in the 1980s.

Feminist critics in the 1960s and 1970s were not focused on theory but were occupied with locating women authors in the early modern period and comparing their 'images' of women with 'images of women' in the works of male authors of the period. As a result of the general movement toward theory in literary studies, feminist criticism became more theoretically focused to the point of relying upon other theoretical paradigms, such as Marxist and cultural materialist theory, in order to expand the possibilities of feminist analysis. However, there are feminist critics who avoid theoretical analysis, judging it to be patriarchal. While queer theory can be seen as an equally fraught discipline, the 'problems' derive from a different source. Queer theory did not 'arrive' until after the poststructuralist influx of theory. Hence, it has always already been a highly theoretical mode of analysis. The fact that it developed in response to texts by avowedly 'queer' (gay, lesbian, bisexual, transgender, and so on) authors of the nineteenth and twentieth centuries presents a problem for analyses of early modern texts that are not as 'visibly' queer as later ones. One major split operating within queer theory in early modern studies occurs along the gay/lesbian binary. How can queer theoryor gay studies - be applied to texts of a period that had few women authors and even fewer 'avowedly' lesbian ones?

My personal critical agendas are feminist, and I explore the various ways gender is construed in the early modern period. I examine the avenues of power open to women, the ways in which marriage allowed or restricted a 
woman's power, and the extent to which women formed alliances with other women. ${ }^{1}$ When feminist critics consider how women react/interact with other women, they sometimes skirt the issue of affectionate/erotic congress. At this point I see alliances between feminist and queer theory. Marxist/cultural materialist inspired feminist theory looks at women as Other within all aspects of patriarchal society. Queer theory looks at all the 'others' who are not sexually active heterosexuals. My critical alliances, therefore, include Marxist/ cultural materialist theory along with feminism and queer theory so that, by examining the various kinds of Others upon whom these theories focus, I can gain a more nuanced picture of how female subjectivity is presented/revealed/ questioned/challenged/demonized within early modern dramatic texts.

In 'Theorizing and Repoliticizing Feminist Theory in Early Modern Studies', chapter 1 of my book Women in Power in the Early Modern Drama, I looked at how the various strains of feminist criticism at the end of the twentieth century both assisted and restricted literary analysis of early modern texts. ${ }^{2}$ My project was to analyze the representation of women rulers in early modern plays in terms of how they utilized inherited power and how such utilization differed from that of male rulers. Much feminist criticism at that time relied upon essentialist archetypes or Freudian psychoanalysis, ${ }^{3}$ or was profoundly anti-theory, ${ }^{4}$ so that it was difficult to analyze women ruler characters. Not only were archetypes of women rulers non-existent, but Freudian analysis was based upon the concept of the late nineteenth-century upper middle-class family, a structure remarkably different from the early modern family. Theorizing gender development from such a different construct seemed impossible. Yet patriarchal societies at all times and places do depend upon the power of those whom the society defines as 'male' over those whom it defines, for whatever reasons, as 'non-male'. In terms of twentiethcentury psychoanalytic criticism, therefore, the concept of (male)Self/(female)Other was useful for looking at early modern texts and characters. Even more helpful were the methodologies of new historicism and Marxist/ cultural materialist theory which examined the sociopolitical and cultural implications of patriarchal society and the power relationships between its various binaries of Self and Other, notably the relationships between classes in power and those on the margins. Feminist theory now became richer as a result of these alliances. What $\mathrm{I}$, as an early modern scholar, could not do because of the focus of feminist theory on nineteenth- and twentieth-century societies and texts, I could do by allying feminist theory with new historicism and Marxist/cultural materialist theory. Queer theory, however, was prob- 
lematic for understanding women-women eroticism in the early modern period.

Queer theory developed in response to nineteenth- and twentieth-century gender positions of literary characters. To 'organize' theoretical discussions of gay or lesbian or bisexual authors or characters, Teresa de Lauretis suggested: 'In a sense, the term "Queer Theory" was arrived at in an effort to avoid all of these fine distinctions [of lesbian, gay, etc.] in our discursive protocols, not to adhere to any one of the given terms, not to assume their ideological liabilities, but instead to both transgress and transcend them - or at the very least problematize them. ${ }^{5}$ De Lauretis here indicates one of the paradoxes of queer theory, namely that while critics may want to 'organize' the various 'parts' of the theory, the overall concept of queer theory acts as a means by which the critic can 'transgress and transcend' any restrictive characteristics of a particular 'part' of queer theory. As Alexander Doty maintains, the concept of 'queerness should challenge and confuse our understanding and uses of sexual and gender categories'. ${ }^{6}$ Both de Lauretis's and Doty's theoretical positions ultimately challenge the regime of heterosexuality. Yet as much as we may believe that such a regime 'existed' during the early modern period, it is impossible to attach such a construct to a period that did not distinguish between people who took same-sex or other-sex lovers, and whose catch-all term 'sodomite' had a remarkably shifting definition. ${ }^{7}$ To use queer theory to examine early modern texts I needed two other theorists to help complete the bridge to earlier centuries: Eve Kosofsky Sedgwick and Penelope Englebrecht. Sedgwick defines 'queer' in an extremely inclusive way: 'one of the things that "queer" can refer to', she writes, is

the open mesh of possibilities, gaps, overlaps, dissonances and resonances, lapses and excesses of meaning when the constituent elements of anyone's gender, of anyone's sexuality aren't made (or can't be made) to signify monolithically. The experimental linguistic, epistemological, representational, political adventures attaching to the very many of us who may at times be moved to describe ourselves as (among many other possibilities) pushy femmes, radical faeries, fantasists, drags, clones, leatherfolk, ladies in tuxedoes, feminist women or feminist men, masturbators, bulldaggers, divas, Snap! queens, butch bottoms, storytellers, transsexuals, aunties, wanna-bes, lesbian-identified men or lesbians who sleep with men, or ... people able to relish, learn from, or identify with such. ${ }^{8}$

Despite the fact that Sedgwick does not indicate a place for virgins or celibates in her list of sexual practices, its very inclusivity allows its use for exploring 
early modern sexual relationships that were both unnamed and unconceptualized. Penelope Englebrecht helped to complete my bridge.

As I indicated, feminist critics who base their theories on the patriarchal family accept the premise that the Self - the organizer, power-holder, social creator and definer - is always male and always defines the Other. Usually that Other is female, but Other may also encompass any category of persons who are 'not-yet male' - for example, male children - or those who 'nevercan-be male' - for example, women, sexual others, racial others, aliens, and so on. If we accept this formulation, then any sexual Other is necessarily a social Other, denied the primary social positioning of the Self. How then can we examine the relationships between sexual Others within patriarchal society? Englebrecht addresses this problem in her formulation of SubjectOther/self to describe relationships between lesbians. ${ }^{9}$ Her formulation is useful because it gestures toward the Self/Other binary of patriarchal society, in which straight women and lesbians are Other, yet it also indicates a relationship that differs from the heterosexual Self/Other division to which straight women are pointed. While I feel that Englebrecht's Subject-Other/ self formulation still privileges one partner - I would prefer a formulation such as 'Subject-Other/Subject' or 'Self-Other/Self' - she does break ground in theorizing a way for non-normative sexual relationships to be schematized within patriarchal society and explained in early modern terms.

As an example of how I use the alliances of these various theoretical modalities, I will consider Thomas Dekker's The Honest Whore, ${ }^{10}$ which allows me to analyze the often-demonized whore in concert with two other early modern female character 'types'. Part I of the play, co-authored with Middleton, presents us with three main women characters: Infelice, Viola, and Bellafront. The first two are recognizable character types which have been explored by many critics. Infelice is, against her will, the 'dutiful' daughter who has been mewed up by her farther to prevent her marriage to an unacceptable suitor. Her appearances are brief, and she demonstrates the role of, especially, upper-class women of the period. ${ }^{11}$ Viola, the city wife, represents the opposite end of the spectrum of female behaviour: the shrew. Not content to have a kind, hard-working linen-draper husband whose flourishing business can support three apprentices, Viola cannot accept her husband's patience. At times she is justified, as when some courtiers buy a minuscule amount of fine linen cut from the centre of her willing husband's bolt; but otherwise she is presented as a foolish, noisy woman whose goal is to make her husband angry. She represents the extreme of Infelice's compliance, and 
shows how unacceptable female behaviour causes problems for good men such as being confined to Bedlam.

I realize that a feminist analysis can reveal much about these characters. However, combining feminist theory with Marxist/cultural materialist theory can reveal much more about the cultural milieu of the early modern period and specifically about social attitudes toward daughters and wives. Feminist criticism has made important observations about prostitutes and cultural attitudes toward them, ${ }^{12}$ but I do not want to consider the eponymous Bellafront solely as the demonic cultural opposite of the 'chaste, silent, and obedient' daughter and wife. While feminist critics have indicated that the category 'whore' is a patriarchal attempt to contain a specific type of sexual Other, they have often not considered the socially constructed nature of the term/category 'whore', nor considered these women, as I do, to be queer. Additionally, they have not considered how whores relate to the marketplace and the development of capitalism in early modern England. ${ }^{13}$ Combining queer theory with feminist and Marxist/cultural-materialist theory provides a multi-faceted way to consider the character Bellafront and to allow for a more profitable 'unlocking' of her subjectivity.

We usually see Bellafront entertaining groups of men, rather than individual 'customers', or being pressured to embellish a dinner sponsored by court gallants. While she teases and provokes these men, it is unclear whether she engages in sexual intercourse with them. She clearly receives remuneration, or she could not support herself as a privileged potential companion. Yet she seems not to be bound to comply with all of her guests' wishes. For example, she is bidden to dinner by a group of gallants, yet never appears. They deride her absence, yet do not hint that her failure to appear will diminish either her desirability or their 'patronage' of her. If whores in general are perceived as opposing early modern culture's mandate that women be chaste, silent, and obedient, how is it that Bellafront can live so well - in a material sense - in this culture? ${ }^{14}$

I am arguing that Bellafront lives so well because she is queer. To begin with, she is a successful capitalist. All workers commodify themselves on the labour market by selling their labour for less than it is worth to their employer. The surplus profit thus enriches the capitalist who hires them. Common whores who service numerous customers 'sell' (actually 'rent') their bodies out at a profit for their 'owners', pimps, or bawds. Like labourers, they receive less for their 'labour' than the labour is worth, the profit going to their employers. Bellafront differs from these whores in that she labours solely for herself. No bawd or pimp appears to control her, so she earns the profit 
generated by her labour. And that labour may be primarily the rental of the 'presence' of her body for conversation, dinner parties, and so on, rather than the actual physical use of it. ${ }^{15}$

I also want to argue that the concept of 'queer', one that challenges the regime of heterosexuality, can (and should) be used to examine women characters like Bellafront who appear to occupy one place in society - in this case 'whore' - but who in reality occupy a much more radical subject position. There may be many reasons why a woman becomes a whore, but in a conversation with Matheo, Bellafront indicates that she became one as the result of one sexual encounter with him:

You were the first

Gaue money for my soul; you brake the Ice,

Which after turnd a puddle: I was led

By your temptation to be miserable:

I pray seeke out some other that will fall,

Or rather (I pray) seeke out none at all.

Matheo replies: Ist possible, to be impossible, an honest whore! I haue heard many honest wenches turne strumpets with a wet finger; but for a Harlot to turne honest, is one of Hercules labours' (11. 100-3). The description of Bellafront represents the true cultural circumstance. 'Breaking the ice' is the same as 'de-flowering', and refers to the fact that a woman's first experience of sexual intercourse with a man moves her irrevocably out of the category of virgin. ${ }^{16}$ The man's identity, and the circumstances under which the penetration occurs, determine the future direction of the woman's life. If the virgin is penetrated by her husband, the act moves her into the category of chaste wife. If the man is not her husband, the act moves her into the category of whore. That a woman's first penetration by a man is irreversible is evident in Matheo's speech quoted above; it is easy to make a virgin a whore, impossible to make a whore chaste. Or so it seems. Bellafront realizes that there is one way:

You [and all men] gladly seeke our sexes ouerthrow,

But not to rayse our states; for all your [Matheo's] wrongs,

Will you vouchsafe me but due recompence,

To marry with me?

Matheo's response demonstrates the cultural impossibility of making a whore honest: 
Math. How, marry with a Punck, a Cockatrice, a Harlot? mary

foh, Ile be burnt thorow the nose first.

Bell.: Why la? these are your othes: you loue to vndo vs,

To put heauen from vs, whilst our best houres waste:

You loue to make vs lewd, but neuer chaste.

(11. 116-20)

Despite Matheo's reply, Bellafront articulates a way to resolve the culturally impossible: how to make the unchaste chaste.

I have chosen to focus on Bellafront because her character can best be understood through the combined use of feminist and queer theory. If the character were simply a woman who made the wrong choice and was condemned to a life on the fringes of society, it would be easy to analyze her using feminist theory alone. But Bellafront cannot easily fit into feminist theoretical paradigms. Entirely aware of how her culture constructs the unchaste woman, this character creates a sexual and social role for herself that is contrary to social expectations of women: it is queer. Not content to accept the position of 'whore', Bellafront creates herself as a capitalist courtesan who is the sole beneficiary of her labour. In a culture in which virtually no women were capitalists in the world of trade, Bellafront is a capitalist in the world of sex work. Granted, there have been pimps and bawds before Bellafront, but she is both bawd and whore profiting from her own body, not someone else's.

But the most queer aspect of Bellafront's character involves her desire to challenge her culture's sexual mores, to reverse the accepted trajectory from virgin to whore. By demanding marriage from Matheo she attempts to erase all subsequent sexual encounters with other men after her deflowering. Her queerness is obvious not only in her reversal of cultural expectations, but in her use of sexual knowledge of Matheo to force him to comply. Prostitutes 'normally' possess only a demonic power in early modern plays. Bellafront's power seems 'unnatural', in that it reverses the social order, yet it is honest in that it removes her 'criminality' and restores her to social acceptability. Bellafront demands an end to the unfairness of male control of female bodies by insisting that her deflowerer marry her and change her from unchaste to chaste woman. I would also argue that Bellafront's 'criminality' results primarily from socially imposed definitions. Society is, in fact, 'criminal' in creating the 'outlaw' category of 'whore' for women who disobey social strictures. The power that allows Bellafront to succeed in her transformation to chaste woman is the result of her queerness. Despite her 'fall', Bellafront has managed to maintain her economic independence as well as her personal integrity. Unlike other whores in early modern plays - Kate Keepdown and 
Doll Tearsheet, for example - Bellafront controls her body, chooses her customers, and keeps her substantial profits. She also persuades Matheo to marry her, thus re-defining and re-creating herself as a chaste wife. All of these tasks are outside of the usual capabilities of most women in early modern society or of women characters in the early modern theatre. Queer theory, a methodology that looks at how non-normative sexuality can be examined and theorized, allows me to examine these unusual character traits and produce a nuanced reading of Bellafront.

Part II of The Honest Whore becomes an interesting 'corrective' to Part I. ${ }^{17}$ Of the three main characters in the first play, the dutiful daughter, Infelice, is rewarded with the husband she desires; and the shrewish wife, Viola, is taught the foolishness of her ways and the value of her husband. Such traditional outcomes cast Bellafront's queer dénouement in Part I in a very strange light. What began as a traditional city comedy, Part I became instead a radical play that allowed for a successful challenge to the social status quo by an unchaste female character. Part II, on the other hand, seems a reaction against the challenges of the earlier play, one that works judiciously to restore an accepted social framework in which women characters occupy predictable positions. The shrewish wife, Viola, is killed off in the interval between the two plays, and Candido remarries. And Infelice discovers - as do most women who marry, even those who marry for love - that her husband is intent on cheating on her.

The most interesting character development in Part II, however, is Bellafront's. From the courtesan who controlled her life and refused direction by anyone, Bellafront becomes an abject, obedient wife. Such a change can be viewed, as new historicist critics might, as a recuperation of the queer power evidenced in the character in Part I. Rather than leave at large a character so determined to challenge social protocols regarding the role of women and the definition of chastity, in Part II Dekker reins her in. That is a valid reading of the relationship between the two Bellafronts. But I want to suggest a variant of that reading, one that rescues Bellafront from being interpreted as a 'Patient Griselda' figure. In addition to being a courtesan, Bellafront in Part I is intelligent, witty, and autonomous. She is also 'honest' in that she deals in a straightforward manner with her clients. Her honesty is also evident, I would argue, in her falling in love with Hippolyto. Although that relationship is never consummated, both characters discuss its implications openly and with respect to and for each other. As a result of these discussions, and Bellafront's realization that Hippolyto will not give up his love for Infelice, she decides to become socially honest and marry Matheo. 
If we accept 'honesty' as one of Bellafront's main character traits, and not just as a synonym for 'chaste', we can better understand her behaviour as Matheo's wife. Once she becomes a wife, the honest Bellafront accepts the social definition of the role of wife as 'chaste, silent, and obedient', and she obeys Matheo in all, including pawning her clothes while she is wearing them. But while the character is willing to do whatever she can for her husband, she does not violate her chastity, especially when Matheo suggests that she should supplement the grocery money by turning the occasional trick. Her honesty is also apparent as she tries to keep the servant Pacheco (her father Orlando Friscobaldo in disguise) from leading her husband astray, and Hippolyto from cheating on his wife Infelice. But in order to accomplish these things, Bellafront needs to employ the intelligence she demonstrates in Part I. Thus while the Bellafront of Part II is a boringly honest wife, it is still necessary that she be intelligent to protect her honour, her husband's life, their dwindling finances, and Hippolyto and Infelice's marriage. That she manages to reconcile herself with her father and earn a financial reward shows how necessary intelligence is in a wife. That intelligence is more important than patience also raises once again the issue of the queerness of this character. Early modern marriage theory does not demand intelligence or courage in a wife, though clearly they are characteristics that can aid any woman in managing a household and a recalcitrant husband.

The character Bellafront cannot be considered a 'lesbian' in twenty-first century terms. Nor, I expect, can the Iraqi woman I mentioned at the beginning of this essay, though I have no way of knowing that for sure. My point in using queer theory in analyzing Dekker's 'whore' is not to suggest a homoerotic or homosexual aspect to her character, but to argue that the broad precepts of queer theory allied with feminist and Marxist/cultural materialist theory are valuable for critical analyses of characters who can be rendered one-dimensional when viewed through the lens of a single critical methodology. Considering Bellafront 'queer' because she does not fit the mould of the good early modern woman allows me to consider her radicalness and the ways in which her character challenges social and cultural expectations. Similarly, the unnamed Iraqi woman I have described as 'queer' manages to point out some very dreadful truths about the 'democratic' 'liberators' of her country.

Theodora A. Jankowski 


\section{Notes}

1 See my book Pure Resistance: Queer Virginity in Early Modern English Drama (Philadelphia, 2000) and the following articles: '... in the Lesbian Void: Woman-Woman Eroticism in Shakespeare's Plays', The Feminist Companion to Shakespeare, Dympna Callaghan (ed) (London, 2000), 299-319; 'Pure Resistance: Queer(y)ing Virginity in William Shakespeare's Measure for Measure and Margaret Cavendish's The Convent of Pleasure', Shakespeare Studies 26 (1998), 218-55; and "where there can be no cause of affection": Redefining Virgins, Their Desires, and Their Pleasures in John Lyly's Gallathea', Feminist Readings of Early Modern Culture: Emerging Subjects, Dympna Callaghan, M. Lindsay Kaplan, and Valerie Traub (eds) (Cambridge, 1996), 253-74.

2 Theodora A. Jankowski, Women in Power in Early Modern Drama (Urbana, IL, 1992).

3 Examples include The Woman's Part: Feminist Criticism of Shakespeare, Carolyn Ruth Swift Lenz, Gayle Greene, and Carol Thomas Neely (eds) (Urbana, 1980); Linda Bamber, Comic Women, Tragic Men: A Study of Gender and Genre in Shakespeare (Stanford, 1982); Judith Kegan Gardner, 'Mind Mother: Psychoanalysis and Feminism', Making a Difference: Feminist Literary Criticism, Gayle Greene and Coppélia Kahn (eds) (London and New York, 1985), 113-45; Nancy Chodorow, The Reproduction of Mothering: Psychoanalysis and the Sociology of Gender (Berkeley, 1978); and Coppélia Kahn, 'The Hand that Rocks the Cradle: Recent Gender Theories and Their Implications', The M(o)ther Tongue: Essays in Feminist Psychoanalytic Interpretation, Shirley Nelson Garner, Claire Kahane, and Madelon Sprengnether (eds) (Ithaca and London, 1985), 72-88.

4 See, for example, Carol Thomas Neely, 'Constructing the Subject: Feminist Practice and the New Renaissance Discourses', English Literary Renaissance 18.1 (Winter 1988), 5-18; Ellen Messer-Davidow, 'The Philosophical Bases of Feminist Literary Criticisms', New Literary History 19.1 (Autumn 1987), 65-103; Nina Baym, 'The Madwoman and Her Languages: Why I Don't Do Feminist Theory', Feminist Issues in Literary Scholarship, Shari Benstock (ed) (Bloomington, 1987), 45-61; and Lynda E. Boose, 'The Family in Shakespeare Studies; or - Studies in the Family of Shakespeareans; or - The Politics of Politics', Renaissance Quarterly 40.4 (Winter 1987), 707-42.

5 Teresa de Lauretis, 'Queer Theory: Lesbian and Gay Sexualities: An Introduction', differences 3.2 (1991), v. 
6 Alexander Doty, Making Things Perfectly Queer: Interpreting Mass Culture (Minneapolis and London, 1993), xvii.

7 See Gregory W. Bredbeck, Sodomy and Interpretation: Marlowe to Milton (Ithaca and London, 1991), especially chapter 1.

8 Eve Kosofsky Sedgwick, 'Queer and Now', Tendencies (Durham, 1993), 8. See also Sedgwick's Epistemology of the Closet (Berkeley, 1990), 25-6. Neither Sedgwick nor any other late twentieth-century theorist considers those who do not engage in genital sexuality - for example, virgins and celibates - as queer. Active sexuality, of whatever kind, is presumed in virtually all definitions of 'queer' except my own.

9 Penelope J. Englebrecht, in "Lifting Belly is a Language": The Postmodern Lesbian Subject', Feminist Studies 16.1 (1990), 85-114, argues for a rearticulation of the term Subject-Object for defining lesbian desire. She coins the terms 'Subject and Other/self to indicate 'two categories ... equal in power and value.... each lesbian [is] essentially complete in herself-hence, Self and Other/self. The Desire therefore multiplies our voices, rather than enscribes division.... The lesbian Subject Desires the lesbian Other/self who Desires her' (92).

10 Part I of the play was first published in 1604. Part II was published in 1630; however, it was entered in the Stationers' Register in 1608.

11 See, for example, Suzanne W. Hull, Chaste, Silent \& Obedient: English Books for Women 1475-1640 (San Marino, CA, 1982); on shrewish wives, see Lynda E. Boose, 'Scolding Brides and Bridling Scolds: Taming the Woman's Unruly Member', Shakespeare Quarterly, 42.2 (1991), 179-213, and Frances E. Dolan, introduction to The Taming of the Shrew: Texts and Contexts (Boston and New York, 1996), 1-38.

12 See Anne M. Haselkorn, Prostitution in Elizabethan and Jacobean Comedy (Troy, NY, 1983) and Ruth Mazo Karras, 'The Regulation of Brothels in Late Medieval England', Signs: A Journal of Women in Culture and Society 14 (1989), 399-433.

13 Along with many other scholars, I see capitalism beginning in England with the development of trading companies and the creation of urban class hierarchies based upon a person's relationship to trade or capital (see my essay 'Class Categorization, Capitalism, and the Problem of "Gentle" Identity in The Royall King and the Loyall Subject and Eastward Ho? forthcoming in Medieval and Renaissance Drama in England 18 [2005]). Some feel more comfortable using the term 'proto-capitalist' to refer to this period.

14 The city culture of the play's 'Milan' is virtually indistinguishable from that of London, even to the name of its madhouse. Consequently, I want to divorce from this analysis the early modern idea of 'Italy' as an alien cultural milieu. 
15 In act 2, scene 1, Fluello, Castruchio, and Pioratto invite Bellafront to dinner that evening. She refuses. While Matheo is the only one who believes he can command Bellafront's obedience, the others are willing to change the date to achieve her presence, even if her acquiesence is the vague 'Well' (2.1.221) (Thomas Dekker, The Honest Whore, Part I, in vol. 2 of The Dramatic Works of Thomas Dekker, Fredson Bowers [ed] [Cambridge, 1964]; all quotations from the play will refer to this edition). If we do not realize Bellafront's independence in this interchange, her comment to Hippolyto, 'I am in bondes to no man' (2.1.258), should do so.

Mistress Fingerlock, defined in the cast list as 'a bawd', is a confusing character. She appears in only one scene (3.2), in which she and Bellafront's servant, Roger, lament the financial losses they suffer from Bellafront's exit from the profession. But since Bellafront lives alone in her own establishment, I question to what degree Fingerlock is her bawd. If Bellafront were bound to her, would not Fingerlock exercise more control? In the course of this scene, Roger and Fingerlock revise their financial arrangement, thus reinforcing the capitalist nature of prostitution in this patriarchal society.

16 According to Jonathan Gil Harris, in 'This is Not a Pipe: Water Supply, Incontinent Sources, and the Leaky Body Politic', Enclosure Acts: Sexuality, Property, and Culture in Early Modern England, Richard Burt and John Michael Archer (eds) (Ithaca and London, 1994), 203-28, in the pamphlet The Dead Tearme 'Dekker uses water as a pathological figure for the threat presented to the body politic's health by the excessive incontinence of both its members and its enemies' (211). For example, 'Dekker identifies' Letchery's '“outrageous waters” with prostitution' (212).

17 The Honest Whore, Part II, in vol. 2 of The Dramatic Works of Thomas Dekker, Fredson Bowers (ed).

\section{Transversal Poetics and Fugitive Explorations: Subject Performance, Early Modern English Theatre, and Macbeth}

The 2003-2004 war on Iraq, perpetrated in the wake of the 2001 attacks on the United States and subsequent invasion of Afghanistan, emphasized for me more than any other event so far in my lifetime the need for activism, critical inquiry, and pedagogy that is rigorous, theoretical, and socially and politically engaged. Societies worldwide are rapidly becoming more interconnected through mass media, transportation, and commerce; and the means by which people compete and negotiate for resources and power are becoming progres- 
sively multifaceted, industrious, insightful, and more desperate. Governments and corporations dance with the ebb and flow of capitalism's power; they demonstrate repeatedly that a combination of ingenuity and deception - for example, the Bush and Blair administrations' ability to equivocate or mislead about such things as evidence for weapons of mass destruction - is typically requisite for the successful manipulation and dominance of discourses, societies, markets, and nations.

Developments in technology, culture, and science give the impression that societies are moving faster and getting 'better' than ever, and previously uncharted terrains - ideational and/or material - are explored, graphed, occupied, or subsumed. Exponentially, super-powered nations (the United States, Great Britain, China) and super-empowered iconic concepts and institutions (Christianity, Satan, Capitalism, Islamic Jihad) generate via 'sociopolitical conductors' influential products, such as texts, systems, and students. Sociopolitical conductors are the familial, religious, juridical, media, and educational structures that interconnect a society's ideological framework. ${ }^{1}$ The interrelations among the conductors and their products effectuate conceptually dynamic assemblages, what I call 'articulatory spaces', that are discursive environments which surround, enmesh, embody, and laminate charged topics, objects, and events, thereby furthering their dissemination of 'open power', 'state power', and/or 'transversal power'. ${ }^{2}$ Within and through articulatory spaces these powers escalate and radiate both diachronically and synchronically, affecting people in significant ways: sociocultural economies negotiate and function in conjunction with the articulatory spaces through which they develop; and through this engagement people come to see and believe certain things, consequently undergoing subjective 'becomings' and 'comings-to-be' as the result of poignant and repeated performances. ${ }^{3}$

Performing, experiencing, thinking, reading, and/or writing about any culturally dominant iconic subject, whether sports, popular music, film, or literature, and the iconic subject's myriad permutations necessitate becomings, comings-to-be, and a passing-through of spacetime thresholds. When encountering or embodying any media conceptually and/or materially imbued or manifested by an icon's 'affective presence' (the combined material, symbolic, and imaginary existence of a concept/object/subject/event), we become situated as participants within articulatory spaces and their overlappings and fusions, in much the same way that subsets and their elements work in mathematical set theory. ${ }^{4}$ For instance, Shakespeare's affective presence (as marvellous poet, cultural icon, or ideological symbol) engages us with the phenomena of what Donald Hedrick and I have termed 'Shakespace', a term 
that encompasses the plurality of Shakespeare-related articulatory spaces and the time and speed at which they move through places, cultures, and eras. ${ }^{5}$

By explaining our relationships to the articulatory spaces through which we evolve, I hope to reveal how such spaces, especially the literary-culturalcritical spaces that have influenced our understandings of subjectivity in early modern England and today, can be political, empowering, and artistically inspiring. The 'investigative-expansive mode' of analysis that guides the praxis of 'transversal poetics', ${ }^{6}$ the critical approach, theory, and aesthetics that I have developed to combat the disempowering of people that has been encouraged by much humanist, poststructuralist, psychoanalytic, and new historicist discourse, and to foster agency and creativity, as well as the production of more conscientious and socially purposeful scholarship and pedagogy, has led me to propose a particular methodology that I call 'fugitive explorations'. Operating within the framework of boundless potential proposed by transversal theory, fugitive explorations call for readings of a given text that defy the authorities that reduce and contain meanings, both of the readings and of the text itself. Dominating authorities can be found in all readings and reading environments, both of a text's inception and point of reception; they are the past, present, and future interpretive communities that constrain them; they are the interested authorities who channel and situate a text and its interpretations across spacetime, arbitrarily producing its history and value. Hence, 'fugitive explorers' venture wherever they are drawn, reconstituting parameters accordingly, as they strive to uncover fugitive elements - human, narrative, thematic, semiotic, and so on - of the subject matter being examined and the environments in which it has been contextualized, particularly those that pressurize the authorities and, by extension, the communities necessary for the substantiation of the authorities' power. In effect, fugitive explorers often endow agency where agency had been wanting, evacuated, or forbidden.

Politically invested fugitive explorations might, for example, involve an attempt to link transversally within history, culture, and metaphysics the ectoplasmic traces of the ghost-characters of Shakespeare's Cymbeline, Julius Caesar, Macbeth, and Hamlet in productions of the plays (theatrical and literary-critical) and in other artifacts. The purposes of this undertaking might be to give voice to commonly marginalized or elusive perspectives on or of the ghost-characters, to highlight opinions about the phenomena of ghosts across history, cultures, and disciplines, and to engage with scientific theories that might illuminate in unexpected and productive ways the ghostly subject matters under investigation. In response to queries about the fact that 
transversal poetics makes no overarching or definitive claims with regard to its specific political investments, but rather remains as fluid and case-specific in its determinations as the ideas, opportunities, and methodology it promulgates, I offer fugitive explorations as a derivative, transversal approach with a pronounced agenda: to understand and empower fugitive elements insofar as doing so generates positive experiences.

To elucidate some of the distinct characteristics and advantages of fugitive inquiry within and beyond transversal poetics, I want to turn now to a comparison with the philosophy and methodology of deconstruction, as formulated by Jacques Derrida. Like deconstruction, fugitive explorations pursue slippages, loose threads, and latent signifiers in a chosen text as a means by which to undermine and unravel the text's apparent meanings for a given interpretive community or communities. Unlike deconstruction, however, it does this deliberately as a gateway to other possible readings and, by extension, to other conceptual, emotional, and physical localities. Thus, fugitive explorations do more than merely expose the instability of texts and the semiotic systems in which they function. It would not be enough to show how the witches in Macbeth, for instance, undermine through prevarication or powers of suggestion the patriarchal system within the play. The fugitive explorer might also relate Shakespeare's representation of witches to dissident or exploitative occasions precipitated by the circulation of certain seductive or misleading concepts outside of the play text (in, for example, contemporary advertising campaigns, religious institutions, or college classrooms) as a means by which to illuminate types of becomings, comings-to-be, and subject performances that make possible, encourage, or inspire, at least conceptually, such currently hotly debated cognitive interventions as leading the witness and faith healing.

Finding potentialities in instabilities, as in the case of Macbeth's witches, fugitive explorations emphasize the text's possible meanings beyond its intended, immediate, or future audiences. A goal of transversal poetics in and through fugitive explorations is to discourage blinkered, hermeneutical reductionism, such as of the kinds that force an investigation to bow down willy-nilly to overdetermined concepts like historicism, presentism, or futurism. Unlike deconstruction, transversal poetics asks that we consider artifacts positively and extensively, rather than define negatively, defer continuously, or dismiss alternative interpretations and applications by relying only on dialectical argumentation. Yet it also asks, like deconstruction, that we remain aware that there is no inherent, absolute, or unmediated meaning or subject position; that truth and perception are processual and contingent; and that 
any text or social identity (like Derrida's own writings and affective presence) can be made to deconstruct itself endlessly, through what Derrida calls 'différance', by replacing one supplemental, always already indeterminate meaning after another, each standing in for the never-to-be-found conclusion or transcendental signified. Nevertheless, while this can be a valuable approach, especially when implemented to undermine rhetoric and systems that are employed to oppress people, it often leaves unanswered questions significant to people, like our students, who want to relate the literary text in question to issues pertinent to their lives.

When studying Macbeth, for instance, students often contemplate who is ultimately responsible for Macbeth's actions. They are usually unsatisfied when I suggest to them that the play is merely words, 'a tale / Told by an idiot, full of sound and fury, / signifying nothing' (5.5.27-8), ${ }^{7}$ as the play itself suggests, and that no one is responsible because there is nothing there but indeterminacy for which anyone could be provisionally responsible. Instead, my students have defined a range of culpable agents: Duncan, the inept and careless ruler; Macbeth, the naïve, ambitious, and weak would-be king; Lady Macbeth, the power-mongering emasculator; the witches, who are prophetic and interfering; Shakespeare, the authorial agent; the early modern English society that produced Shakespeare; and we, the immediate interpreters of the play. My point is that who or what is responsible for Macbeth's actions matters only inasmuch as we can productively associate the question, examination, and possible answers with issues important to people today, and positively - to people 'tomorrow, and tomorrow, and tomorrow' (Macbeth 5.5.19). As scholars and teachers, this is our responsibility.

As fugitive inquiry works to reveal portholes and expand passages, fostering travel into disparate territories, it does not pursue or resolve comfortably with the nihilism of deconstruction or with the notion of infinity that it invokes (the fugitive explorer is never a caged gerbil forever spinning on a treadmill). Nor does fugitive inquiry privilege any axioms, including the influential psychoanalytic and post-Marxist axioms that define desire and subjectivity as predicated on lack. Fugitive inquiry is not a victim or victim-making approach. For transversal theory, subjectivity is processual and develops positively through becomings and comings-to-be; this often occurs through the recognition of differences, but not typically or desirably as a consequence of negation. Accordingly, compensation or totalization is not the objective of fugitive explorations, although sustaining an understanding may be a welcomed outcome. Informed by transversal theory, fugitive explorations recognize limits within circumstances and agents even while remaining steadfastly 
committed to both the concept that anything is possible and the fact that there is a real where things are, happen, and can be done, however difficult to access or influence, and however subject to mediation and a matter of perception. This is where fugitive inquiry most departs from deconstructionist analysis, as well as from the poststructuralism of theorists as different and antithetical as Jean Baudrillard and Judith Butler.

Fugitive explorations can also expose, either wilfully or inadvertently, hidden elements that are disempowered because they can no longer operate covertly. For instance, once unknown enemies are identified and locatable, their deconstructionist mission, subversive potential, or state power can be weakened or diverted inasmuch as they can be quashed or co-opted. Consider, for example, Caliban's recognition and subsequent manipulation of Trinculo and Stephano as power-hungry, lustful human beings (The Tempest 3.2). Either way, through the exploratory process, the investigative-expansive thinker becomes fugitive as a means by which to move transversally outside of what I have termed one's own 'subjective territory,' the combined conceptual, emotional, and physical range from which a given subject perceives and experiences the world. ${ }^{8}$ Fugitive explorations can work to get people outside of their subjective territories through such 'transversal movements': feelings, thoughts, and actions alternative to those that work to circumscribe and maintain one's particular subjective territory, and, by extension, the greater 'official territory' comprised of the subjective territories of a society's members.

The transversal inclination is always fugitive to the subjectified, but not all transversal movement is fugitive on every level. Someone occupying conceptual, emotional, and/or physical spacetimes alternative to those prescribed by an official culture has moved out of her subjective territory, is expanding her experiential range, possibly disidentifying with her established social role, and is self-referentially acting fugitively. If someone's transversal movement works in the interest of dominant sociopolitical conductors to institute predominantly a subjective territory that reinforces official culture, thereby promoting the overarching 'state machinery' that the conductors together comprise, the dissident potential of the fugitive action can diminish for that person. This might occur if a member of a criminal group violates the group's codes, thereby becoming fugitive to the group, and inadvertently supports the mainstream culture against which the group defines itself. Whatever the outcome, the person's transversal movement may nonetheless serve as a model that inspires others to wander.

Theatre happens when a performance is presented to an intended audience that is aware of an interpretive frame specific to that performance. As an event, 


\section{Issues in Review}

in effect, of performance, theatre is often an exemplary model of the kind of apparatus that induces transversal wanderings through processes of becomings-other and comings-to-be-other, such as of other social identities, species categories, or spiritual beings. Theatre spurs these wanderings through the phenomena of identification, empathy, projection, hypothesis, and/or transference. As I have demonstrated elsewhere, this was especially the case for early modern England's public theatre. The metatheatrics and naturalistic impersonations that characterized the public theatre, unlike allegorical presentations in pageants and morality plays, challenged established beliefs about the singularity and cogency of reality and, by extension, the traditional sexual, gender, moral, and class differentiations that depended on those beliefs. The public theatre posited all social categories, such as 'man' and 'woman', as constructs that must be performed in order to be. It suggested that the body (with or without genitalia) matters only inasmuch as it is a point of departure for identity becomings. ${ }^{9}$

The lived reality of the public theatre's transversal influence in early modern England - of the theatrespace engendered there - can be seen especially in the vehement antitheatrical discourse and actions taken against the theatre. Yet the transversal influence of the theatre was most manifest in the workings of criminals and social deviants, such as individuals who disguised themselves as gypsies in order to extort money, sell herbal remedies, and read palms, con men who pretended to be different people in order to perpetrate crimes, and people who practiced transvestism, whether male-tofemale in the theatre or female-to-male on London's streets, the latter having become a popular fashion contemporaneous with the public theatre's popularity. The transversal power of the public theatre transgressed the Church's ideology and corresponding official culture, undermining the properties of the society's interiority that endeavoured to organize and monitor via sociopolitical conductors the subjective territories of the society's members.

Whether through theatre or critical inquiry, fugitive explorations can be precarious undertakings because they challenge, defy, and promote the defiance of authorities (personal, cultural, governmental), which can lead to real consequences, including social metamorphosis, combat, punishment, and liberation. Transversal movements, moreover, are often corollary to fugitivity, and can take one deep into 'transversal territory', a multidimensional space encompassing, among other known and unknown qualities, the nonsubjectified regions of all individuals' conceptual and emotional range. Thus, movement into transversal territory could cause the wayward traveler to experience a cognitive disjunction that is often pathological, taking the form 
of a dream-like state of altered consciousness in which themes are lost and reappear, possibly over and over again (the waking nightmare or living dream of the deconstructionist). Such persistent occupation of transversal territory can be counterproductive if the goal of the fugitive explorer is to emancipate readings of the text, and/or herself, and/or others in order to achieve agency. Certainly Macbeth's irresistible transversality, influenced by his quest for what he cannot know, pushes his subject performance into what zooz eloquently terms a 'progressive quagmire':

Progressive quagmires are research states, indeed states of being (if you will), that are manifest when the analytical tools which were believed to fuel progress prove unable to resist the analysis' momentum and thus are incapable of generating new directionality and expansion because the analysis is pushed along a rigid course. And yet the researcher, having experienced past "successes" with them, and being urged on by social, cultural, political, and paradigmatic conventions, is reluctant to part with these investigative tools and, by extension, the (de)limiting assumptions underlying them. ${ }^{10}$

To avoid progressive quagmires by becoming fugitive analytically, and therefore to ferret out fugitive components of a system, narrative, psyche, and so on, one frequently has to journey into the hypothetical dimensions of 'subjunctive space'. Because the fugitive is mysterious, perhaps already on the run, elusive, and/or burrowing in the nooks and crannies of discourse, the transversalist engages subjunctively in atypical possibilities for meaning and articulation: the 'what ifs' and 'as ifs' that the text (or life experience) may or may not inspire. Taking you with me into subjunctive space, I would like to turn to a brief example, a fugitive dabble of sorts, into the early modern English discourse on equivocation, which is a subject of my forthcoming book Fugitive Explorations. ${ }^{11}$

Early modern England's dominant religious ideology maintained that God orders and Satan confuses, a determination that reverberates, for instance, in Macduff's response to the revelation of King Duncan's murder: 'Confusion now hath made his masterpiece!' (Macbeth 2.3.65). This God-Satan dynamic resounds throughout Macbeth as equivocation (in language and action) and is associated with witchcraft and the Jesuit conspirators who attempted to blow up King James and Parliament in the Gunpowder Plot of 1605. In particular, Shakespeare's use of the word 'equivocation' by the Porter $(2.3 .8-9 ; 2.3 .30-2)$, as has often been observed, references $A$ Treatise of Equivocation, written by early modern England's clandestine Jesuit leader, Father Henry Garnet (1555-1606), describing the language and gesture one 
can use to provide deceptive answers under oath without retribution from God. The general employment of equivocation in Macbeth, especially by the witches, who 'draw' Macbeth into 'confusion' (3.5.29), mislead him with riddles - 'none of woman born' (4.1.79), 'Birnam wood' (4.1.93), 'palter with us in double sense' (5.8.20) - demonstrates through discourse and performance the presence of Satan within the play's world and beyond as it aligns the play's witches with both real witches and the Jesuits, who were thought to be 'devil-conjuring priests', as Samuel Harsnett describes them in A Declaration of Egregious Popish Impostures (1603). ${ }^{12}$

Witches and Jesuits, like all of Satan's underlings and emissaries, were seen as outlaw infiltrators working to promote chaos in God's otherwise orderly universe; and since equivocation encourages doubt, and wherever there is doubt there is evidence of Satan's work and further opportunity for Satan to undermine order and goodness, equivocation was seen as a threat to all cosmic structures, moral authority, and societal coherence, which is to say, state power. As documented by Edward Casey, according to medieval and early modern England's prevailing ideologies, God both created the universe and occupies particular places within it, and to challenge this idea, even under the auspices of hypothesis, was considered heretical and treasonous. ${ }^{13}$ In fact, it was clear to early moderners that God occupies some individuals and places more than others, such as pious people, churches, and heaven, God's presence being measured by the 'goodness' found in them. But if we consider alternative theories of being, metaphysics, and subjectivity emergent toward the end of the sixteenth century and developing throughout the seventeenth, as articulated, for example, through the logic behind the Jesuits's use of equivocation, the extent to which the notion of dissemination and particularity was commonly held becomes questionable.

While researching with my collaborators (especially Donald Hedrick) representations of deceit in early modern English discourse on performance, my fugitive explorations, moving investigative-expansively beyond the text of Macbeth and the other texts it typically invokes, led me to what I believe is a hitherto unaddressed connection between the discourse on equivocation and an unprecedented change in perceptions of place as a possible location for either Godly or Satanic interventions. Of the momentous historical seachanges of the sixteenth and seventeenth centuries, including the Copernican system, the great vowel shift, the public theatre, nascent capitalism, and colonial expansion, this important conceptual revolution has often been ignored, although it connects all of these revolutions. I refer to the transformation of the concept of place in relation to the concept of space. While the 
change was complex and variously expressed, and occurred over several centuries, it has been generally charted in the history of ideas by Casey as a move toward a de-emphasis of the idea of place as it had been construed in Aristotelian/Ptolemaic and Christian philosophical traditions. By the early modern period, place began to lose its status, indeed its affective presence, as it was subsumed by the notion that God is infinite space (recall that Hamlet speaks of divine kings as occupying 'infinite space' [2.2.255]). ${ }^{14}$ It was no longer thought that God occupied particular places within the infinite space that he created, but rather that his presence was infinite. He was now thought to be in all places at all times, thereby making a concept of place irrelevant inasmuch as human beings are made in God's image; for if God could not occupy a discrete subject position from which to observe the universe he created, neither could human beings.

Inspired by Casey's work on place, I searched for references to time and space in early modern England's commercial literature and noted that England's early moderners, many years before Sir Isaac Newton published his understanding of space and time as absolute states, conceived of people as existing in the infinite space that is God, and thus accounted for infinite time as well. For instance, Shakespeare often makes time and space synonymous, as in 1 Henry VI, where things happen 'after three days' space' (3.2.294), or as in Love Labour's Lost, where the action spans 'three years space' (1.1.52). ${ }^{15}$ Therefore, because people equated space with God and God with time, hence seeing them all as the same substance, what makes equivocation radical in relation to this revolutionary change in the history of ideas is not just that the ambiguity it produces allows for Satanic interventions. The acknowledgment of the everywhereness of God in the logic behind the employment of equivocation - of God occupying placelessness because he is in all places at once - that anticipated and contributed to the succession of space over place that gave way to the scientific revolution also implies a radical understanding of subjectivity. A causal, reciprocal relationship between this new idea of God's pervasiveness/placelessness and the idea of an open-ended phenomenology ironically problematizing the Cartesian subject - who knows he exists because he thinks, but only knows this because God is the source of truth who bestows thought itself - is supported by the theories of Galileo Galilei and is later crystallized in Newton's third law of motion, in which the actions of two bodies upon each other are always equal and directly opposite. Unfortunately for some people, such as the seventeenth-century Dutch philosopher Baruch Spinoza, who was less willing to veil his subscription to this fugitive concept of relational effect than was Newton, the fact that this 
law leaves no room for Satan, or, inversely, for God, resulted in their displacement. Indeed, the radical ramification of the all-places/all-times model of God is that it leaves no room for the concept of autonomous and/or individuated subjectivities; it posits subjectivity as always pluralized, infused, and collective; subjects appear unique and differentiated only insofar as they convince each other that they are individuals through framing and performance, which is to say, through theatre.

To conclude, I want to suggest that by moving investigative-expansively across spacetime one could intriguingly compare the everyspacetimeness of God imagined by early moderners to the every-elsewhereness of 'pure evil' and the placelessness of weapons of mass destruction repeatedly equivocated by the Bush and Blair administrations. In conjunction, one might also consider the subjective interconnectedness that generated the very articulatory spaces, friendly and/or adversarial, of which Bush's affective presence is reciprocally contributory. Fugitive explorations encourage us to do so.

Bryan Reynolds

\section{Notes}

1 See Bryan Reynolds, 'The Devil's House, "or worse": Transversal Power and Antitheatrical Discourse in Early Modern England' (Theatre Journal 49.2 [1997], 143-67); Becoming Criminal: Transversal Performance and Cultural Dissidence in Early Modern England (Baltimore, 2002), 1-22; and Performing Transversally: Reimagining Shakespeare and the Critical Future (New York, 2003), 1-28.

2 'Open power' is any power that does not fall under the categories of 'state power' or 'transversal power'. 'State power' is any force that works in the interest of coherence and organization among any variables. 'Transversal power' is any force that inspires emotional, conceptual, and/or physical deviations from the established norms' for any variables, whether individuated or forming a group.

3 'Becoming is a desiring process by which all things (energies, ideas, people, societies) change into something different from what they are. If the things had been identified and normalized by some dominant force, such as state law, religious credo, or official language, then any change in them is, in fact, becomings-other' (Reynolds, Becoming Criminal, 20-1). As Glenn Odom and 
I further explain in our essay 'Pressurized Belongings and the Coding of Ethnicity, Religion, and Nationality in Shakespeare's Titus Andronicus' (in my Transversal Enterprises in the Drama of Shakespeare and his Contemporaries: Fugitive Explorations [London, forthcoming 2005]), "“comings-to-be-other" occur when the subject loses control during the process of becomings-other and becomes more (of/or something else) than anticipated and/or desired. In other words, becomings are active engagements, often self-inaugurated and pursued intentionally, whereas comings-to-be, however spurred by becomings, are generated by the energies, ideas, people, societies, and so on to which the subject aspires, is drawn toward, or happenstantially encounters'.

4 See Reynolds, Becoming Criminal, 1-22; and Performing Transversally, 1-28.

5 See Donald Hedrick and Bryan Reynolds, introduction to Shakespeare Without Class: Misappropriations of Cultural Capital, Hedrick and Reynolds (eds) (New York, 2000), 3-47; and Reynolds, Performing Transversally, 1-28.

6 See Reynolds, 'The Devil's House', 143-67; Becoming Criminal, 1-22; and Performing Transversally, 1-28.

7 William Shakespeare, Macbeth, Kenneth Muir (ed) (London, 1951). All quotations from Macbeth will refer to this edition.

8 See n. 6 above.

9 Reynolds, Becoming Criminal, 150.

10 zooz, 'Transversal Poetics: I. E. Mode', GESTOS: Teoría y Práctica del Teatro Hispánico 18.35 (2003), 13.

11 See n. 3 above. For more on 'subjunctive space' see Reynolds, Performing Transversally, 1-28.

12 Samuel Harsnett, A Declaration of Egregious Popish Impostures (1603; STC 12880), 149.

13 Edward S. Casey, The Fate of Place: A Philosophical History (Berkeley, 1997).

14 William Shakespeare, Hamlet, Harold Jenkins (ed) (London, 1982).

15 William Shakespeare, The First Part of King Henry VI, Andrew S. Cairncross (ed) (London, 1962); Love's Labour's Lost, Richard David (ed) (London, 1968). 